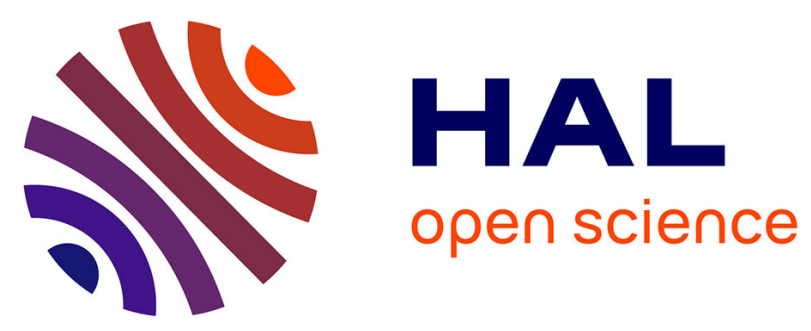

\title{
Purification of pentoses from hemicellulosic hydrolysates without neutralization for sulfuric acid recovery
}

Claire-Line Blanc, Julien Lemaire, Fanny Duval, Marc-André Théoleyre, Dominique Pareau

\section{- To cite this version:}

Claire-Line Blanc, Julien Lemaire, Fanny Duval, Marc-André Théoleyre, Dominique Pareau. Purification of pentoses from hemicellulosic hydrolysates without neutralization for sulfuric acid recovery. Separation and Purification Technology, 2017, 174, pp.513-519. 10.1016/j.seppur.2016.10.042 . hal01481027

\section{HAL Id: hal-01481027 \\ https://hal.science/hal-01481027}

Submitted on 2 Mar 2017

HAL is a multi-disciplinary open access archive for the deposit and dissemination of scientific research documents, whether they are published or not. The documents may come from teaching and research institutions in France or abroad, or from public or private research centers.
L'archive ouverte pluridisciplinaire HAL, est destinée au dépôt et à la diffusion de documents scientifiques de niveau recherche, publiés ou non, émanant des établissements d'enseignement et de recherche français ou étrangers, des laboratoires publics ou privés. 


\section{Purification of pentoses from hemicellulosic hydrolysates}

\section{without neutralization for sulfuric acid recovery}

Claire-Line Blanc, Julien Lemaire*, Fanny Duval, Marc-André Théoleyre, Dominique Pareau

LGPM, CentraleSupélec, Université Paris-Saclay, SFR Condorcet FR CNRS 3417, Centre Européen de Biotechnologie et de Bioéconomie (CEBB), 3 rue des Rouges Terres 51110 Pomacle, France

\section{Abstract}

The agro-industrial sector generates large amounts of coproducts such as lignocellulosic biomass which could be valorized into many chemicals and bio-based intermediates (sugars, paper pulp, surfactants, polymers or bioethanol). However, in the case of biomass hydrolysis by diluted sulfuric acid, current downstream processes involve a partial or complete neutralization which are not satisfactory for economic and environmental reasons.

This work presents a purification process of pentoses from hemicellulosic hydrolysates without neutralization for sulfuric acid recovery.Compared to conventional processes, less energy, water and chemicals are required.Very promising results were obtained at pilot scale with $100 \mathrm{~L}$ of wheat bran hydrolysates. The process is based on the combination of ultrafiltration, conventional electrodialysis and ion-exchange.

Ultrafiltration witha $10 \mathrm{kDa}$ organic membrane totally removed harmful macromolecules which precipitate during electrodialysis operation because of $\mathrm{pH}$ rise. Till a volumetric concentration factor 3.6, the average flux kept good for industrial application $\left(27 \mathrm{~L} . \mathrm{h}^{-1} \cdot \mathrm{m}^{-2}\right)$. However suspended materials have to be filtered before ultrafiltration. Besides, a 2.5 diafiltration is requiredto recover most of sugars (99\%).

Then conventional electrodialysis was performed to recover most of sulfuric acid $(80 \%)$. The average faradic yield was quite good $(80 \%)$ and the specific energy consumption of the electrodialysis stack was quite interesting (1.1 kWh per $\mathrm{kg}$ of $\mathrm{H}_{2} \mathrm{SO}_{4}$ recovered and 8.4 
$25 \mathrm{kWh}$ per $\mathrm{m}^{3}$ of hydrolysate). Finally, the complete demineralization (conductivity $<10 \mu \mathrm{S}^{\mathrm{cm}} \mathrm{cm}^{-}$

$26{ }^{1}$ ) and discoloration (420 nm absorbance $<0.01$ ) of the sugars solution was performed by

27 ion-exchange and an activated carbon polishing treatment. The sugars purity was close to

$28100 \%$ meanwhile the overall sugars recovery rate reach about $90 \%$. Finally we checkedthat

29 the reused sulfuric acid solution was as efficient as a fresh one in a second hydrolysis

30 operation of wheat bran. Recovery rates could be increased by a scale-up operation or a

31 continuous mode of the process.

32 Keywords: pentoses; purification; acid recycling; electrodialysis; green chemistry.

33

34

35

36

37

38

39

40

41

42

Email address: julien.lemaire@centralesupelec.fr

${ }^{*}$ Corresponding author.

Tel.: +33(0) 352620502.
- Purification of pentoses from hemicellulosic hydrolysates without neutralization.

- Recycling of sulfuric acid for hydrolysis of lignocellulosic biomass.

- Decrease of water and chemicals required for hydrolysate demineralization.

- Combination of ultrafiltration, electrodialysis and ion-exchange.

Present address: CentraleSupélec, CEBB, 3 rue des Rouges Terres 51110 Pomacle, France. 


\section{Introduction}

Chemical industry has shown a rapid growth in the 20th century thanks to petroleum as carbon source. Oil has indeed become the base for almost every product made by industrial chemistry. However this field is now facing a new challenge because of global warming mostly due to the accumulation of carbon dioxide (greenhouse gas) into the atmosphere. Moreover oil is a fossil carbon resource whose world stocks are inevitably sinking while its price is strongly fluctuating. This is the reason why green chemistry is growing in many fields due to its advantages: carbon economy, more efficient syntheses, but alsonew renewable carbon sources.

Lignocellulosic biomass is considered as a very promising source of renewable carbon. A significant part is used by agro-industries, such as food- or forestry industries, generating large amounts of coproducts (wheat straw and bran, sugar beet pulp, wood waste ...), which are often poorly valorized [1]. Many chemical compounds and bio-based intermediates (sugars, paper pulp, surfactants, polymers or bioethanol) can however be produced from these lignocellulosic residues [2,3].This valorization of every part of crop is the goal of the biorefinery concept.

Among those residues, bran is the major by-product of wheat milling [4]. Bran is produced in very large quantities but is mainly used as livestock feed. Wheat bran is mainly composed of hemicellulose $(20-40 \% w)$, starch $(10-20 \%$ w), protein $(15-22 \% w)$, cellulose $(9-15 \% w)$ and lignin $(4-10 \%$ w) [5-7]. Arabinoxylans constitute the major part of wheat bran hemicellulose; therefore wheat bran is an attractive source of pentoseswhich have found growing applications, such as xylitol, surfactants and biopolymers productions [8].

Hydrolysis is necessary to extract monosaccharides from cellulose and hemicellulose. This chemical pretreatment is generally difficult and requires drastic conditions, such highly alkaline or acidic media or use of organic solvents, like ethanol [9].A complex mixture of hexoses, pentoses, lignins and ashes is produced, needing further downstream separations. 
This work studies the purification of pentoses obtained by hydrolysis of wheat bran withdiluted sulfuric acid as a catalyst $[9,10]$.The classical separation methods involve ionexchange [11-13], chromatography, adsorption or crystallization [14-16], but need a partial or complete pre-neutralization of the inorganic acid. Those processes are not sustainable as they consumea lot of chemicalsand energy.Most notably large amounts of base are necessary to neutralize the acid catalyst, which is then lost for further hydrolysis. Besides, neutralization increases dramatically the amount of mineral salts which have to be removed in a further step.

Electrodialysis (ED) was studied here as an alternative to neutralization, allowing direct acid recovery and reducing chemicals consumption. This process is a separation technique using an electrical potential as driving force to move ions through selective exchange membranes to separate them from uncharged species[17]. It is widely used for whey demineralization, in order to produce an ingredient for infant formula [18]. ED is also implemented in bioprocesses for organic acids purification, for example lactic acid [1922].The major drawback of this technique is membrane clogging, leading to significant decreases in production. Indeed, during sulfuric acid extraction, $\mathrm{pH}$ rises and organic matters soluble at low pH (lignin, proteins...) precipitate [23]. This phenomenon strongly reducesboth process efficiency and membrane durability.Macromolecules must then be removed before ED and membrane separation seems appropriate for this purpose[24,25].

A previous lab-scale study revealed the feasibility of sulfuric acid recovery from wheat bran hydrolysate using ultrafiltration followed by electrodialysis[26]. Operating conditions of both steps were optimized as well as the choice of ultrafiltration membranes. The retention of harmful macromolecules was effective only with organic membranes (10 to $50 \mathrm{kD}$ ), even with higher cut-off than ceramic membranes. Indeed, permeate flux and rejection rate are not only determined by pore size, but also by membrane nature, charge and hydrophobicity [27].

The present work aims atinvestigatingthe process feasibility at a larger scale.Indeed, it is necessary to estimate more accuratelyperformances (recovery rates and productivies) that 
could be obtained at the industrial scale. Moreover, the goal was to check the reliability and robustness of membranes for both processes. Furthermore, it was necessary to produce a significant amount of brine (15 g. $\left.\mathrm{L}^{-1} \mathrm{H}_{2} \mathrm{SO}_{4}\right)$ to carry on a new hydrolysis of wheat bran in order to verify the feasibility of acid recycling by our industrial partner.

\section{Materials and methods}

\subsection{Wheat bran hydrolysate}

The hydrolysate, which composition is given in table 1, was produced by an industrial partner by mixing destarched wheat bran with a sulfuric acid solution around $12 \mathrm{~g} \cdot \mathrm{L}^{-1}$. The mixturehas been heated at $130{ }^{\circ} \mathrm{C}$ for 1 hour and roughly filtered after cooling. It was then splitted into three $23 \mathrm{~L}$ tanks. The hydrolysate contained suspended matter, which settled resulting in a roughly clear supernatant and a muddy tank bottom. When the withdrawn supernatant was not enough clear, a centrifugation was performed before further treatments to remove remaining suspended matter at $4000 \mathrm{~g}, 4^{\circ} \mathrm{C}$ for $15 \mathrm{~min}$.

Table 1 -Composition of the wheat bran hydrolysate

\begin{tabular}{ccc}
\hline Total dry weight & $\% \mathrm{w}$ & 8.0 \\
Solubles dry weight & $\% \mathrm{w}$ & 6.9 \\
Dry suspended matter & $\mathrm{g} \cdot \mathrm{kg}^{-1}$ & 11 \\
\hline $\mathrm{pH}$ & - & 1.4 \\
Conductivity & $\mathrm{mS} . \mathrm{cm}^{-1}$ & 34.0 \\
$420 \mathrm{~nm}$ absorbance & - & 1.79 \\
\hline Glucose & & 11.4 \\
Xylose & $\mathrm{g} \cdot \mathrm{L}^{-1}$ & 25.5 \\
Arabinose & & 14.6 \\
Furfural & & 0.8 \\
\hline $\mathrm{H}^{+}$(total acidity) & $\mathrm{mmol} \cdot \mathrm{L}^{-1}$ & 240 \\
\hline $\mathrm{Na}$ & & 6 \\
$\mathrm{NH}_{4}$ & $\mathrm{mg} \cdot \mathrm{L}^{-1}$ & 369 \\
$\mathrm{~K}$ & & 240 \\
\hline Total cations & $\mathrm{meq} \cdot \mathrm{L}^{-1}$ & 27 \\
\hline $\mathrm{SO}_{4}$ & $\mathrm{mg} \cdot \mathrm{L}^{-1}$ & 10375
\end{tabular}




\begin{tabular}{ccc}
$\mathrm{Cl}$ & 59 \\
$\mathrm{PO}_{4}$ & & 913 \\
\hline Total anions & meq. $\mathrm{L}^{-1}$ & 256 \\
\hline
\end{tabular}

112

113

114

115

116

\subsection{Ultrafiltration}

The filtration modulewas an Alfa Laval TestUnit M20, a crossflow membrane filtration unit equipped with a heat exchanger for temperature control, a recirculation pump and a $8 \mathrm{~L}$ stainless steel tank. A 2.5" spiral organic membrane UFX10 pHt was furnished by Alfa Laval for ultrafiltration at a molecular weight cut-off of $10 \mathrm{kDa}$. This membrane was chosen owing to its retention performances and its specific resistance to very acid conditions (till pH 1). The total membrane area was $0.6 \mathrm{~m}^{2}$. The dead volume in the system was estimated to $2 \mathrm{~L}$.

Before filtration, the water flux was measured at $40{ }^{\circ} \mathrm{C}$ with a transmembrane pressure of 5 bar, giving $340 \mathrm{~L} \cdot \mathrm{h}^{-1} \cdot \mathrm{m}^{-2}$. This was the reference to evaluate membrane state after in situcleaning with an alkaline solution (Ultrasil 110, Ecolab). The permeate and retentate have been recirculated to the feed tank for $1 \mathrm{~h}$ (time necessary to heat the feed) before withdrawing permeate and concentrating retentate. A volume higher than the tank volume was filtered in one run, so the run was conducted in fed-batch mode $(1 \mathrm{~L}$ permeate out, $1 \mathrm{~L}$ feed in) at $40{ }^{\circ} \mathrm{C}$ and a transmembrane pressure of 5 bar. Temperature, tank $\mathrm{pH}$ and conductivity and permeate flowrate were monitored.

\subsection{Electrodialysis}

The conventional electrodialysis plant was supplied by Eurodia. It was composed of three

$2 \mathrm{~L}$ tanks containing the electrolyte, the product (ultrafiltered hydrolysate) and the brine (diluted sulfuric acid solution), three pumps for the circulation of each solution and a voltage generator. A conventional 10unit cells stack, with an alternation of anion and cation exchange membranes was used. The unit cell area was $0.02 \mathrm{~m}^{2}$. It was operated at a constant voltage of $14 \mathrm{~V}$ and a free intensity, without temperature regulation. Pumps ensured 
134 a 180 L.h $^{-1}$ flowrate in the brine and feed compartments and a 200 L. $^{-1}$ flowrate in the

135

136

137

138

139

140

141

142

143

144

145

146

147

148

149

150

151

152

153

154

155

156

157

158

159 electrolyte compartment (supplier recommended values).

The electrolyte was a $20 \mathrm{mS} . \mathrm{cm}^{-1} \mathrm{Na}_{2} \mathrm{SO}_{4}$ solution $\left(11 \mathrm{~g} \cdot \mathrm{L}^{-1}\right)$. The initial brine was a 5 mS.cm ${ }^{-1} \mathrm{H}_{2} \mathrm{SO}_{4}$ solution $\left(0.7 \mathrm{~g} \cdot \mathrm{L}^{-1}\right)$. The operation was run in batch mode until the conductivity drop rate was lower than $0.25 \mathrm{mS} \cdot \mathrm{cm}^{-1} \cdot \mathrm{min}^{-1}$. Temperature, $\mathrm{pH}$ and conductivity were monitored.

This unit was optimized for demineralizationby the manufacturer. Operating conditions (flow rates, current, voltage, electrolyte and initial brine composition) were fixed according to manufacturer's recommendations. Conventional ED is performed with a constant tension so the limiting current density is not a constant and decreases during demineralization. Tension was fixed to work always under the limiting current density so as to optimize energy consumption and faradic yield.

During this operation, sulfuric acid was transferred from the feed to the brine through the electric field. Two successive batch operations were performed; acid enriched brine of the first batch was reused in the second batch in order to reachthe acid concentration required to recycleit for wheat branhydrolysis $\left(10-15 \mathrm{~g} \cdot \mathrm{L}^{-1}\right)$.

\subsection{Polishing}

The final product polishing was performed at lab-scale by ion-exchange and activated carbon because both techniques are commonly used and well understood at industrial scale.The goal was to check its final quality and to know in which extent the present process increased the capacity of ion-exchange resins compared to conventional method (neutralization with lime).

Firstly,the product (after ED) was further demineralized by ion-exchange to obtain a conductivity lower than $10 \mu \mathrm{S} . \mathrm{cm}^{-1}$. Two vertical glass columns operating in series were filled respectively with $100 \mathrm{~mL}$ of a strong cationic resin (Lanxess $\mathrm{S} 2528 \mathrm{H}^{+}$form) and $100 \mathrm{~mL}$ of a weak anionic resin (Lanxess $\mathrm{S} 4368 \mathrm{OH}^{-}$form). The product was injected by a peristaltic pump 
at room temperature at $4.0 \mathrm{BV} . \mathrm{h}^{-1}\left(400 \mathrm{~mL} \cdot \mathrm{h}^{-1}\right)$ until the breakthrough point of salts was

161

reached. Its brix, $\mathrm{pH}, 420 \mathrm{~nm}$ absorbance and conductivity were monitored at the output.

Finally the demineralized productwasconcentrated at $40{ }^{\circ} \mathrm{C}$ under vacuum with a rotating evaporator (Büchi), thenpercolated through $50 \mathrm{~mL}$ activated carbon (Chemviron Carbon) by a peristaltic pump at $1.5 \mathrm{BV} . \mathrm{h}^{-1}\left(75 \mathrm{~mL} \cdot \mathrm{h}^{-1}\right)$ at room temperature. Before use, carbon was dropped into boiling water and let for a night within the cooling water.

\subsection{Analytic methods}

Conductivity andpH were measured with a 340i conductimeter/pH-meter from WTW. Dry matter was estimated with a brixmeter (RFM732 Bellingham+Stanley). Sample color was evaluated by measuring absorbance at $420 \mathrm{~nm}$ with a spectrophotometer (UV-1800, Shimadzu).Total sample acidity was quantified by titration with $0.1 \mathrm{M} \mathrm{NaOH}$ solution.

Sugars and furfural were analysed with a HPLC system (Ultimate 3000, Dionex) equipped a RI-101 refractometer (Shodex). The analytical column was an Aminex HPX-87H (Biorad) and its temperature was maintained at $45{ }^{\circ} \mathrm{C}$. The mobile phase was 2 mmol. $\mathrm{L}^{-1} \mathrm{H}_{2} \mathrm{SO}_{4}$ degassed by an on-line vacuum degasser. The flowrate was set to $0.5 \mathrm{~mL} \cdot \mathrm{min}^{-1}$ and the injection volume to $10 \mu \mathrm{L}$.

Anions and cations were analysed with anHPIC system (ICS-5000+, Thermo Scientific Dionex) equippedwith two eluent generators, a column oven controller set to $35^{\circ} \mathrm{C}$ and two suppressors (table 2). Detection is performed by conductivity.

Table 2 -Conditions of ionic chromatography

\begin{tabular}{|c|c|c|c|c|c|}
\hline & Column & $\begin{array}{l}\text { Guard } \\
\text { column }\end{array}$ & Eluent & Suppressor & $\begin{array}{l}\text { Injection } \\
\text { volume }\end{array}$ \\
\hline $\begin{array}{c}\text { Anion } \\
\text { analysis }\end{array}$ & $\begin{array}{c}\text { lonpack } \\
\text { AS11HC } \\
\text { 2x250 mm } \\
\text { (Dionex) }\end{array}$ & $\begin{array}{l}\text { AG11HC } \\
2 \times 50 \mathrm{~mm} \\
\text { Dionex }\end{array}$ & $\begin{array}{c}30 \mathrm{mM} \\
\text { potassium } \\
\text { hydroxide } \\
0.3 \text { mL.min }\end{array}$ & $23 \mathrm{~mA}$ & $2.5 \mu \mathrm{L}$ \\
\hline
\end{tabular}




\begin{tabular}{|c|c|c|c|c|c|}
\hline $\begin{array}{c}\text { Cation } \\
\text { analysis }\end{array}$ & $\begin{array}{l}\text { lonpack } \\
\text { CS16 } \\
3 \times 250 \mathrm{~mm} \\
\text { (Dionex) }\end{array}$ & $\begin{array}{c}\text { CG16 } \\
3 \times 50 \mathrm{~mm}, \\
\text { Dionex }\end{array}$ & $\begin{array}{c}30 \mathrm{mM} \\
\text { methanesulfonic } \\
\text { acid } \\
0.36 \mathrm{~mL} \cdot \mathrm{min}^{-1}\end{array}$ & $32 \mathrm{~mA}$ & $10 \mu \mathrm{L}$ \\
\hline
\end{tabular}

180

181

182

183

184

185

186

187

188

189

190

191

192

193

194

195

196

197

198

199

200

201

202

203

\section{Results and discussion}

\subsection{Ultrafiltration}

Ultrafiltration was carried out to remove the macromolecules present in the hydrolysate, which could precipitate during electrodialysis, due to rising $\mathrm{pH}$. Four batch operations were performed with the same membrane, which was cleaned in situbetween tests. This operation was very efficient since no precipitate was detected in permeate samplesafter rising their $\mathrm{pH}$ to ca. 7 with a $0.1 \mathrm{M} \mathrm{NaOH}$ solution.

For the first trial (UF1) $14 \mathrm{~L}$ of the first tank supernatantwere introduced in the system resulting in $16 \mathrm{~L}$ of initial retentate because of the $2 \mathrm{~L}$ dead volume(centrifugation not required). It was concentrated till a volumetric concentration factor (VCF) 3.6. The initial flux was about $33 \mathrm{~L} \cdot \mathrm{h}^{-1} \cdot \mathrm{m}^{-2}$ and decreased to $16 \mathrm{~L} \cdot \mathrm{h}^{-1} \cdot \mathrm{m}^{-2}$ during the operation, as seen onfigure 1 , resulting in an average flux of $27 \mathrm{~L} \cdot \mathrm{h}^{-1} \cdot \mathrm{m}^{-2}$.

Then the $9 \mathrm{~L}$ remaining of the first tank supernatanthad to be centrifuged because of the suspended matter amount. The pellet contained the major part of the suspended matter as a slurry. However, centrifugation splitted in two the liquid phase.The lighter phase also contained suspended matter in the form of light flocs. Nevertheless, both phases were filtered together and concentrated at VCF 2.7 during the second trial (UF2). A dramatic flux reduction was observed during this operation. The initial flux was only $11 \mathrm{~L} \cdot \mathrm{h}^{-1} \cdot \mathrm{m}^{-2}$ and dropped to 7 L.h $h^{-1} \cdot \mathrm{m}^{-2}$ (figure 1), resulting in an average flux of $8 \mathrm{~L} \cdot \mathrm{h}^{-1} \cdot \mathrm{m}^{-2}$. It must be explained by the increase of membrane fouling with suspended matters and the observed flocs. Moreover, the liquid demixing coulddecrease the transfer velocity at the membrane surface and consequently increase the concentration polarization. Indeed, in a recent work, the improvement of suspended matter removal without using centrifugationlead to better and 
204 sustainable permeate flux $\left(>20 \mathrm{~L} \cdot \mathrm{h}^{-1} \cdot \mathrm{m}^{-2}\right)$.In situ cleaning was performed until recovering a 205 satisfactory water flux (ca. $300 \mathrm{~L} \cdot \mathrm{h}^{-1} \cdot \mathrm{m}^{-2}$ ). The slight decrease of water flux showed that the 206 fouling was quite reversible, so suspended matters had to remain mainly at the membrane 207 surface.

208

209

210

211

212

213

214

215

216

217

218

219

220

221

222

223

224

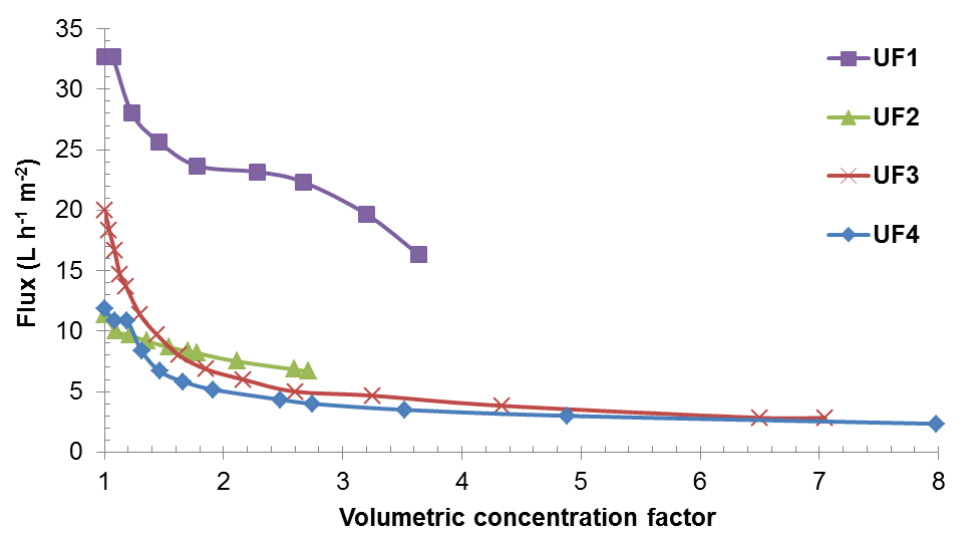

Figure 1 - Evolution of permeate flux as a function of volumetric concentration factor (VCF) for each ultrafiltration trial

The last two tests ( 3 and 4$)$ were performed to concentrate a complete tank volume (ca. $24 \mathrm{~L}$ ) in one batch, achieving a higher VCF than the previous trials. The product was settled.The clear supernatant of each tank was recovered and the rest of the volume was centrifuged. Both liquid phases obtained after centrifugation were mixed to the clear supernatant to get a representative sample of a two phases industrial centrifugation. As seen on figure 1, the trends for both trials were rather similar, except for the initial flux values, and close to the UF2 curve. Indeed after UF3 and alkaline cleaning,it was not possible to reach the initial water flux of $300 \mathrm{~L} \cdot \mathrm{h}^{-1} \cdot \mathrm{m}^{-2}$, but only $200 \mathrm{~L} \cdot \mathrm{h}^{-1} \cdot \mathrm{m}^{-2}$. This highlights that membrane fouling was not totally reversible and some suspended matters was not removed by alkaline cleaning and progressively blocked membrane pores. However,the fouling by soluble macromolecules seems to be more reversible because the removal of suspended matter before ultrafiltration resulted in better and sustainable permeate flux.

The measured average fluxes were respectively of $6.4 \mathrm{~L} \cdot \mathrm{h}^{-1} \cdot \mathrm{m}^{-2}$ and $5.2 \mathrm{~L} \cdot \mathrm{h}^{-1} \cdot \mathrm{m}^{-2}$ for UF3 and UF4. Those values are probably too low for an industrial application, whereas 
225 fluxesobtained during UF1 are very interesting. So it is important to find a way to reach a 226 feed quality equivalent to the UF1 supernatant. Centrifugation does not seem to be the right 227 way as it segregates the liquid phase and produces light flocs. Consequently, before 228 ultrafiltration, the hydrolysate has to be better filtered with membranes which largely reduce, 229 even totally remove, suspended matters.

230 For the fourth ultrafiltration trial, analyses of the feed, the final retentate and the mean 231 permeate are given in table 3.Due to the system dead volume, the initial retentate was 232 slightly more diluted than the feed and its real volume was estimated to $25.2 \mathrm{~L}$. So the final 233 volumetric concentration factor was around 9.5 .Only $88 \%$ of sugars (glucose, xylose and 234 arabinose)were recovered in the permeate; such a sugars loss is not an option for the 235 process viability. So a continuous diafiltration has to be performed after ultrafiltration to 236 increase sugars recovery up to $99 \%$. A 2.5 diafiltration volume should be enough to reach 237 this aim, namely a water volume which corresponds to 2.5 fold the final retentate volume.

Table 3 -Experimental results of UF4 trial andrecovery rates estimation after 2.5 diafiltration

\begin{tabular}{ccccccc}
\hline & Feed & $\begin{array}{c}\text { UF4 Mean } \\
\text { permeate }\end{array}$ & $\begin{array}{c}\text { UF4 Final } \\
\text { retentate }\end{array}$ & $\begin{array}{c}\text { Recovery } \\
\text { rate in UF4 } \\
\text { permeate (\%) }\end{array}$ & $\begin{array}{c}\text { Total recovery rate } \\
\text { after UF4+ 2.5 } \\
\text { diafiltration (\%) }\end{array}$ \\
\hline Volume & $\mathrm{L}$ & 23.2 & 22.5 & 2.7 & 90 & - \\
\hline Dry weight & $\% \mathrm{w}$ & 6.9 & 5.4 & 11.7 & 80 & 97 \\
\hline $\mathrm{pH}$ & - & 1.4 & 1.4 & 1.3 & - & - \\
\hline Conductivity & $\mathrm{mS} \cdot \mathrm{cm}^{-1}$ & 34.0 & 32.7 & 29.1 & - & - \\
\hline Sugars & & 51.6 & 42.8 & 49.9 & 88 & 99 \\
Furfural & g. $\mathrm{L}^{-1}$ & 0.8 & 0.8 & 1.0 & 87 & 99 \\
Salts & & 12.0 & 9.6 & 23.7 & 78 & 98 \\
\hline Total anions & & 247 & 198 & 501 & 77 & 96 \\
Total cations & meq. ${ }^{-1}$ & 27 & 24 & 23 & 90 & 99 \\
Acidity (A- ${ }^{+}$) & & 220 & 174 & 478 & 76 & 95 \\
\hline
\end{tabular}

As a conclusion it is possible to remove efficiently precipitating macromolecules from 241 wheat bran hydrolysate by ultrafiltration with a $10 \mathrm{kDa}$ organic membrane, without losing sugars. Hydrolysate treatment prior to ultrafiltration, for removal of suspended matter, has to 
243 be designed carefully as membrane clogging determines the permeate fluxes of 244 ultrafiltration. The resulting permeate was afterwards demineralized by electrodialysis.

\subsection{Electrodialysis}

Electrodialysis was implemented to extract sulfuric acid from hydrolysatein order to recycle it to the hydrolysis step, provided the solution was concentrated enough in sulfuric acid (10-15 g/L). According to preliminary tests, when the acid enriched brine of the first batch was reused for a second batch, the second brine was suitable in terms of acid concentration.

So $4 \mathrm{~L}$ of ultrafiltered permeate (feed)were demineralized by conventional ED using an initial $2 \mathrm{~L}$ brine of $5 \mathrm{mS} . \mathrm{cm}^{-1}$ sulfuric acid. Around $22 \mathrm{~L}$ of permeate were treated in this way, producing $11 \mathrm{~L}$ of sulfuric acid solution. Results of four trial pairs are presented on figures 2 and 3.The first batches correspond to trials made with fresh feeds andfresh brines. In the second batchesfresh feeds and brines obtained after the first batches were used. The very good reproducibility proved that ion-exchange membrane performances remained quite constant. Consequently, biofouling is expected low and quite reversible. The ultrafiltration step must have removed the most part of macromolecules which can be responsible for biofouling, as well as macromolecules which can precipitate because of $\mathrm{pH}$ rise.

So as to keep productivity high enough, the product was always demineralized untilonly 2 $\mathrm{mS} . \mathrm{cm}^{-1}$ (figure 2); its final $\mathrm{pH}$ was 2.7 . Fromthis moment, the conductivity drop velocity became lower than $0.25 \mathrm{mS} \cdot \mathrm{cm}^{-1} \cdot \mathrm{min}^{-1}$. No precipitation was observed.The brine was enriched in acid from 5 to $40 \mathrm{mS} . \mathrm{cm}^{-1}\left(0.7\right.$ to $\left.8.6 \mathrm{~g} \cdot \mathrm{L}^{-1} \mathrm{H}_{2} \mathrm{SO}_{4}\right)$ during the first batches and up to $65 \mathrm{mS} . \mathrm{cm}^{-1}\left(14.7 \mathrm{~g} \cdot \mathrm{L}^{-1} \mathrm{H}_{2} \mathrm{SO}_{4}\right)$ during the second batches.

Moreover, ED was performed until the product conductivity reached only $2 \mathrm{mS} . \mathrm{cm}^{-1}$ so as to recover most of acids and keep the faradic yield above 50\%. In this case, the average faradic yield remained good $(80 \%)$ and the specific energy consumption of the electrodialysis 
hydrolysate). Better faradic yield was not expected because of high mobility of $\mathrm{H}^{+}$that are 270 more difficult to keep in brine compartment than other cations.

271 It can be seen on figure 3 that the current intensity was also greatly reproducible. The 272 initial intensity of the second batches was higher than that of the first batches due to a 273 higherinitial brine conductivity. After $7 \mathrm{~min}$, both intensities were equivalent due to similar 274 product conductivities.
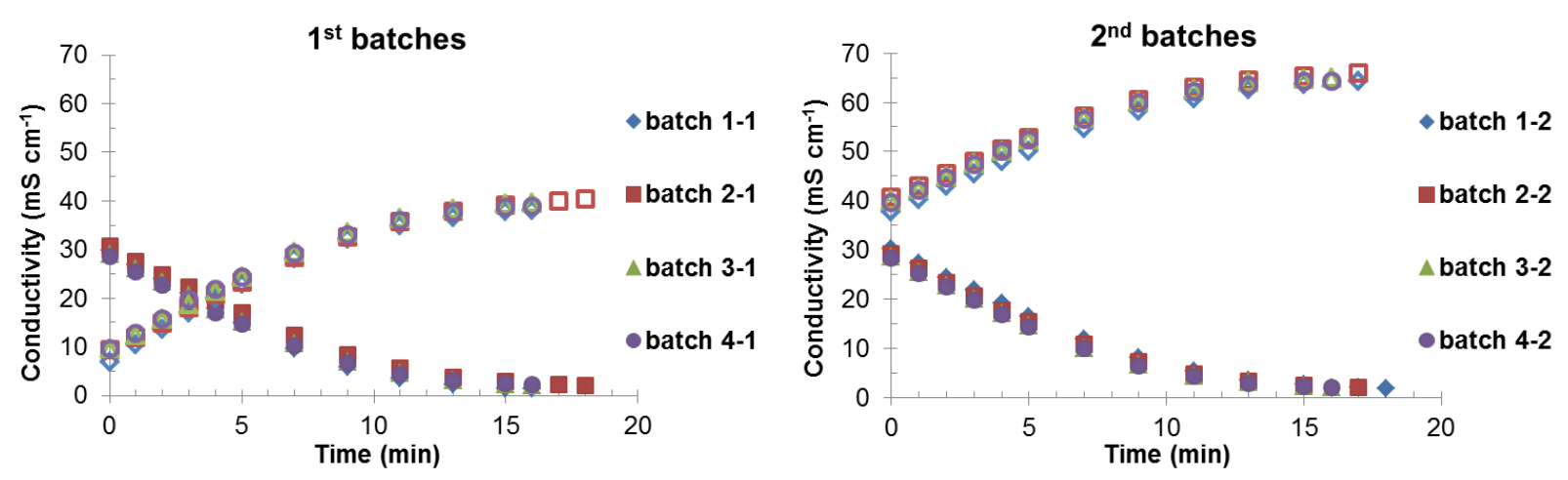

Figure 2 - Evolution of brine (empty symbols) and product (full symbols) conductivities during the first (fresh brine) and second (reused brine) batches

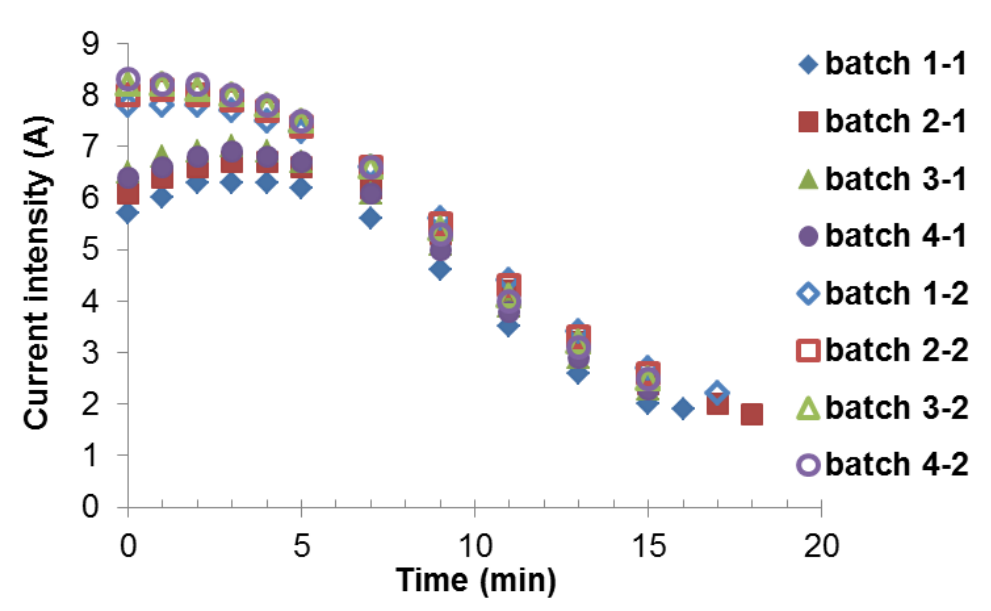

Figure 3 - Evolution of current during the first (full symbols) and second (empty symbols) batches

Demineralized products of all the batches were gathered,as well as the final brines of the second batches. The sugars recovery rate in the products was very good (99\%) (table 4); no

281 sugar went through the ion exchange membranes into the brine. On the contrary $87 \%$ of the 282 acid was recovered into the brine, reaching about $15 \mathrm{~g}^{-\mathrm{L}^{-1}} \mathrm{H}_{2} \mathrm{SO}_{4}$. The resulting brine $\mathrm{pH}$ and concentration were appropriate to perform a new hydrolysis. 


\begin{tabular}{ccccccc}
\hline & & Feed & $\begin{array}{c}\text { Fresh } \\
\text { brine }\end{array}$ & $\begin{array}{c}\text { Mean } \\
\text { product }\end{array}$ & $\begin{array}{c}\text { Mean } \\
\text { brine }\end{array}$ & $\begin{array}{c}\text { Recovery rate } \\
\text { in product (\%) }\end{array}$ \\
\hline Volume & $\mathrm{L}$ & 21.6 & 10.6 & 21.4 & 11.2 & 66 \\
\hline Dry weight & $\% \mathrm{w}$ & 5.4 & 0.1 & 5.0 & 2.4 & 80 \\
\hline $\mathrm{pH}$ & - & 1.4 & 2.1 & 2.4 & 1.3 & - \\
\hline Conductivity & $\mathrm{mS} . \mathrm{cm}^{-1}$ & 32.7 & 5.0 & 2.2 & 70.8 & - \\
\hline 420 nm absorbance & - & 1.79 & & 1.07 & & - \\
\hline Sugars & & 42.8 & 0.0 & 43.1 & 0.7 & 99 \\
Furfural & $\mathrm{g} . \mathrm{L}^{-1}$ & 0.8 & 0.0 & 0.7 & 0.0 & 97 \\
Salts & & 9.6 & 0.7 & 1.1 & 18.0 & 11 \\
\hline Total anions & & 198 & 14 & 27 & 363 & 12 \\
Total cations & $\mathrm{meq} \cdot \mathrm{L}^{-1}$ & 24 & 0 & 1 & 46 & 6 \\
Acidity $\left(\mathrm{A}^{-}-\mathrm{C}^{+}\right)$ & & 174 & 14 & 25 & 318 & 13 \\
\hline
\end{tabular}

The produced brine was then used to carry on a new hydrolysis by our industrial partner.

287 It was mixed with the required destarched wheat bran quantity and heated at $130{ }^{\circ} \mathrm{C}$ during 1 288 hour. No sulfuric acid was added.In order to avoid the centrifugation step, which had a 289 dramatic impact on UF fluxes, the filtration method of suspended matter was improved. Its 290 concentration was clearly reduced (table 5). Similar results must be got with an industrial 291 operating press filter.

292 The composition of the hydrolysate obtained with this recycled brine was very close to the 293 reference (table 5). Only salts concentrations were significantly higher in the case of the 294 recycled brine. Indeed the salts were extracted by ED as well as $\mathrm{H}_{2} \mathrm{SO}_{4}$; but as they are in 295 minor concentrations, it must not be an inconvenient. However this accumulation has to be 296 watched and might require an occasional purge.

Table 5 - Composition of both reference hydrolysate andhydrolysate obtained with recycled brine

\begin{tabular}{cccc}
\hline & \%w & $\begin{array}{c}\text { Reference } \\
\text { hydrolysate }\end{array}$ & $\begin{array}{c}\text { Hydrolysate with } \\
\text { recycled brine }\end{array}$ \\
\hline Dry weight & 6.9 & 7.3 \\
\hline $\mathrm{pH}$ & - & 1.4 & 1.4 \\
\hline Conductivity & $\mathrm{mS} . \mathrm{cm}^{-1}$ & 34.0 & 38.2 \\
\hline
\end{tabular}




\begin{tabular}{cccc}
\hline Dry suspended matter & $\mathrm{g} \cdot \mathrm{kg}^{-1}$ & 11.0 & 0.2 \\
\hline Glucose & & 11.4 & 11.3 \\
Xylose & & 25.5 & 26.8 \\
Arabinose & $\mathrm{g} \cdot \mathrm{L}^{-1}$ & 14.6 & 15.4 \\
Furfural & & 0.8 & 1.1 \\
\hline $\mathrm{SO}_{4}$ & & 10375 & 12514 \\
$\mathrm{Cl}$ & $\mathrm{mg} \cdot \mathrm{L}^{-1}$ & 59 & 196 \\
$\mathrm{PO}_{4}$ & & 913 & 1610 \\
\hline Total anions & $\mathrm{meq} . \mathrm{L}^{-1}$ & 256 & 334 \\
\hline $\mathrm{Na}$ & $\mathrm{mg} \cdot \mathrm{L}^{-1}$ & 6 & 358 \\
$\mathrm{NH}$ & 369 & 632 \\
$\mathrm{~K}$ & & 240 & 513 \\
\hline Total cations & $\mathrm{meq} . \mathrm{L}^{-1}$ & 27 & 64 \\
\hline
\end{tabular}

298

299 The feasibilityof recycling sulfuric acid was thendemonstrated. The whole process 300 including suspended matter filtration, $10 \mathrm{kDa}$ ultrafiltration with organic membrane, 2.5 301 diafiltration and conventional electrodialysis, seems to be reliable with a very good 302 reproducibility. The recycled brine was successfully used for hydrolysis of destarched wheat 303 bran.

304 Overall recovery ratesin the brine (sulfuric acid) and the product (sugars, furfural) were 305 calculated and summed up in table 6.The sugars recovery rate was limited by the dead 306 volume of the UF pilot device; a continuous operationandthe scale-up could easily improve 307 the recovery rates, by limitinglosses due to the system dead volume. Sugars purity was of 308 84\%; further purification steps would be necessary to reachhigherpurities.

Table 6 -Performanceof the global process before polishing treatment

\begin{tabular}{cc}
\hline Sugars recovery in product & $94 \%$ \\
Furfural recovery in product & $92 \%$ \\
Acid recovery in brine & $79 \%$ \\
Sugars purity & $84 \%$ \\
\hline
\end{tabular}


After electrodialysis, the major impurities in the sugar solutionwere salts, furfural and 312 organic elements (color); the remaining acid concentration was about $0.3 \mathrm{~g} / \mathrm{L}$. A polishing by 313 ion-exchange and adsorption is necessary to remove salts and organic molecules. Previous 314 electrodialysis step allowed to divide conductivity by fifteen and salts concentration by nine. 315 Thus ion-exchange capacity (expressed as treated volume per ion-exchange resin amount) 316 was expected to be much higher thanobserved capacity with conventional purification 317 methods including a first step of acid neutralization with soda or lime.

Figure 4 presents the evolution of the composition of demineralized fractions, at the output of the ion-exchange system, as a function of injected volume of electrodialyzed product (one bed volume (BV) corresponded to $100 \mathrm{~mL}$ ). Up to15 BV of electrodialyzed hydrolysate were demineralized with a resulting conductivity lower than $10 \mu \mathrm{S} . \mathrm{cm}^{-1}$ during one batch. The product was also completely decolorized $(420 \mathrm{~nm}$ absorbance $=0.00)$. Moreover the furfural concentration was reduced by $58 \%$.As a comparison the same treatment was realized on a hydrolysate only neutralized with lime, as it is done in the conventional process. Only 2 BV weredemineralized before resin saturation. This clearly highlights the advantages of the present process, which greatly reduces chemicals and water consumption, in particular for resin regeneration.

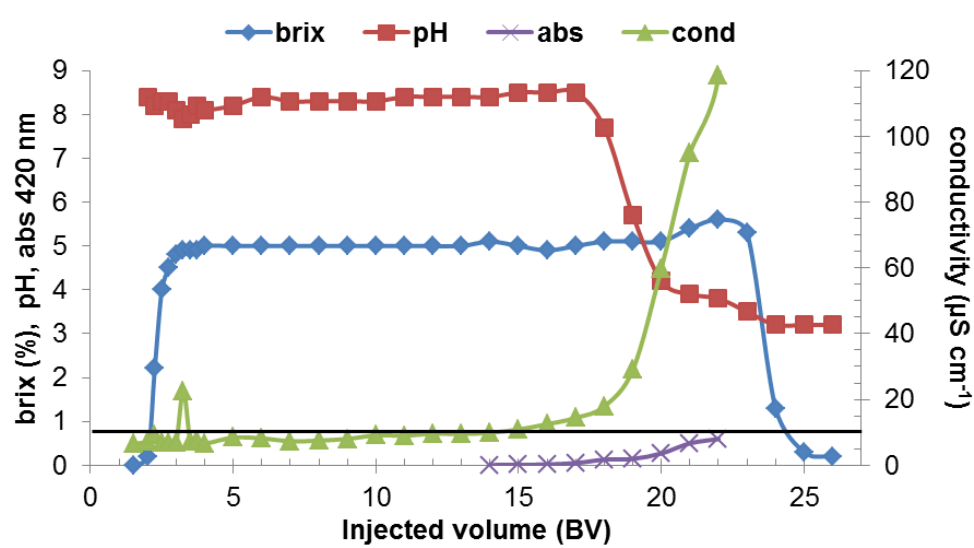

Figure 4 - Evolution of brix, pH, $420 \mathrm{~nm}$ absorbance and conductivity during ion-exchange treatment In order to eliminate remaining furfural, the product was treated after concentrationby activated carbon. The initial product dry weight $(4.9 \%$ w) was increased by concentration up to 
$33252.2 \% \mathrm{w}$, without losing sugars. A minor increase in coloration was also observed with 420 $333 \mathrm{~nm}$ absorbance risingfrom 0.00 to 0.07 . The product composition afterconcentration and 334 activated carbon treatment was summed up in table 7. Furfural and color were totally 335 removed. The sugars recovery rate for the global process, including rough filtration, 336 ultrafiltration, 2.5 diafiltration, conventional electrodialysis and polishing, reached $90 \%$ with 337 apurity close to $100 \%$. Sugars can afterwards be separated classically by continuous 338 chromatography or crystallization [14-16].

Table 7 - Composition of wheat bran hydrolysate after activated carbon treatment

\begin{tabular}{lcccccc}
\hline & $\begin{array}{c}\text { Dry weight } \\
\% \mathrm{w}\end{array}$ & $\mathrm{pH}$ & $\begin{array}{c}\text { Sugars } \\
\mathrm{g} / \mathrm{L}\end{array}$ & $\begin{array}{c}\text { Conductivity } \\
\mu \mathrm{S} . \mathrm{cm}^{-1}\end{array}$ & $\begin{array}{c}\text { Abs } 420 \mathrm{~nm} \\
-\end{array}$ & $\begin{array}{c}\text { Furfural } \\
\mathrm{g} / \mathrm{L}\end{array}$ \\
\hline Purified product & 33.7 & 4.9 & 385.0 & 38.5 & 0.00 & 0.0 \\
Recovery rate & $>99 \%$ & - & $>99 \%$ & - & - & $0 \%$ \\
\hline
\end{tabular}

340

\section{Conclusion}

This work is a significant contribution for the valorization of agricultural by-products as

343 wheat bran. It presents a reliable process for the purification of hemicellulosic sugars,

344 reducing chemicals and water consumption. Ultrafiltration is carried out with an organic 345 membrane in a first time to remove precipitating macromolecules. Afterwards conventional 346 electrodialysis allows the sulfuric acid recovery from hydrolysate in order to recycle it for the 347 hydrolysis step. ED is a key step as it allows a doublechemical saving: less fresh sulfuric acid 348 is needed for hydrolysis and no alkaline chemicals are consumed to neutralize acid and 349 precipitate macromolecules. Thus the salts content is considerably decreased, facilitatingthe 350 further demineralization by ion-exchange and also resulting in the reduction ofchemicals 351 consumption. After activated carbon treatment,the product contains only sugars (glucose, 352 xylose and arabinose). They can be separated from each other by continuous 353 chromatography or crystallization.

354 The acid recovery rate in brine after electrodialysis is around $80 \%$, whereas the overall 355 sugars recovery rate after polishing is close to $90 \%$. Both recovery rates could be increased 
by a scale-up operation or a continuous mode of the process, limiting losses due to the system dead volumes.

358 Attention has to be paid to the initial hydrolysate quality, as it influences greatly 359 ultrafiltration fluxes; the improvement of suspended matter filtration method gave better and sustainable permeate flux ( $\left.>20 \mathrm{~L} \cdot \mathrm{h}^{-1} \cdot \mathrm{m}^{-2}\right)$ with the hydrolysate obtained with the reused brine. Moreover during electrodialysis, not only sulfuric acid but also mineral salts are extracted into 362 the brine; their initial concentrations are very low but their accumulation during recycling 363 cycles may require an occasional purge.

\section{Acknowledgements}

The authors would like to thank Fondation Paris-Reims, Région Champagne-Ardenne,

Département de la Marne and Reims Métropole for their financial support and ARD for the hydrolysate supply.

\section{References}

[1] T. Hasunuma, F. Okazaki, N. Okai, K.Y. Hara, J. Ishii, A. Kondo, A review of enzymes and microbes for lignocellulosic biorefinery and the possibility of their application to consolidated bioprocessing technology, Bioresour. Technol. $135 \quad$ (2013) 513-522. doi:10.1016/j.biortech.2012.10.047.

[2] K.K. Cheng, B.Y. Cai, J.A. Zhang, H.Z. Ling, Y.J. Zhou, J.P. Ge, et al., Sugarcane bagasse hemicellulose hydrolysate for ethanol production by acid recovery process, Biochem. Eng. J. 38 (2008) 105-109. doi:10.1016/j.bej.2007.07.012.

[3] H.J. Huang, S. Ramaswamy, U.W. Tschirner, B.V. Ramarao, A review of separation technologies in current and future biorefineries, Sep. Purif. Technol. 62 (2008) 1-21. doi:10.1016/j.seppur.2007.12.011.

[4] M. Prückler, S. Siebenhandl-Ehn, S. Apprich, S. Höltinger, C. Haas, E. Schmid, et al., Wheat bran-based biorefinery 1: Composition of wheat bran and strategies of functionalization, LWT Food Sci. Technol. 56 (2014) 211-221. doi:10.1016/j.Iwt.2013.12.004. 
[6] R. Cripwell, L. Favaro, S.H. Rose, M. Basaglia, L. Cagnin, S. Casella, et al., Utilisation of wheat bran as a substrate for bioethanol production using recombinant cellulases and amylolytic yeast, Appl. Energy. 160 (2015) 610-617. doi:10.1016/j.apenergy.2015.09.062.

[7] R. Zeitoun, Procédés de fractionnement de la matière végétale: application à la production des polysaccharides du son et de la paille de blé, 2011. http://ethesis.inptoulouse.fr/archive/00001508/ (accessed September 11, 2013).

[8] C. Dumon, L. Song, S. Bozonnet, R. Fauré, M.J. O'Donohue, Progress and future prospects for pentose-specific biocatalysts in biorefining, Process Biochem. 47-3 (2012) 346-357. doi:10.1016/j.procbio.2011.06.017.

[9] M. FitzPatrick, P. Champagne, M.F. Cunningham, R.A. Whitney, A biorefinery processing perspective: treatment of lignocellulosic materials for the production of value-added products, Bioresour. Technol. 101 (2010) 8915-8922. doi:10.1016/j.biortech.2010.06.125.

[10] N. Sarkar, S.K. Ghosh, S. Bannerjee, K. Aikat, Bioethanol production from agricultural wastes: An overview, Renew. Energy. 37 (2012) 19-27. doi:10.1016/j.renene.2011.06.045.

[11] J.M. Asko, H. Lauri, Process for making xylose, US Patent 4075406, 1975.

[12] D. Ballerini, F. Nativel, Procédé et unité de production en continu d'un mélange de sucres contenant au moins $80 \%$ de xylose à partir d'un substrat lignocellulosique, FR Patent 2655661 (B1), 1994.

[13] J.A. Ferreira, C.O. Teixeira, S.M. Soares, Process for the production of crystalline xylose from sugar cane bagasse, crystalline xylose obtained by said process, process for the production of xylitol from the said xylose and crystalline xylitol obtained thereby, WO Patent 108739 (A2), 2004.

[14] H. Heikkilä, K. Hyoky, Method for recovering xylose, US Patent 5084104, 1992.

[15] H. Heikkilä, J. Kuisma, M. Lindroos, O. Puuppo, Method of producing xylose, US Patent 6239274, 2001.

[16] H. Heikkilä, J. Lewandowski, M. Lindroos, P. Saari, Process of producing xylose and dissolving pulp, WO Patent 046532 (A1), 2010.

[17] P.V. Vyas, B.G. Shah, G.S. Trivedi, P.M. Gaur, P. Ray, S.K. Adhikary, Separation of inorganic and organic acids from glyoxal by electrodialysis, Desalination. 140 (2001) 47-54. doi:10.1016/S0011-9164(01)00353-8.

[18] B. Batchelder, N. Reading, Electrodialysis method for demineralization of liquid, whey-based material, US5223107, 1993. 
[19] C. Huang, T. Xu, Y. Zhang, Y. Xue, G. Chen, Application of electrodialysis to the production of organic acids: State-of-the-art and recent developments, J. Membr. Sci. 288 (2007) 1-12. doi:10.1016/j.memsci.2006.11.026.

[20] E.G. Lee, S.H. Kang, H.H. Kim, Y.K. Chang, Recovery of lactic acid from fermentation broth by the two-stage process of nanofiltration and water-splitting electrodialysis, Biotechnol. Bioprocess Eng. 11 (2006) 313-318. doi:10.1007/BF03026246.

[21] E. Gyo Lee, S.H. Moon, Y. Keun Chang, I.K. Yoo, H. Nam Chang, Lactic acid recovery using two-stage electrodialysis and its modelling, J. Membr. Sci. 145 (1998) 53-66. doi:10.1016/S0376-7388(98)00065-9.

[22] H.J. Lee, S.J. Ahn, Y.J. Seo, J.W. Lee, A feasibility study on the multistage process for the oxalic acid pretreatment of a lignocellulosic biomass using electrodialysis, Bioresour. Technol. 130 (2013) 211-217. doi:10.1016/j.biortech.2012.12.061.

[23] J.H. Lee, J. An, S. Park, T. Kim, S. Kim, Economic process for producing xylose from hydrolysate using electrodialysis and direct recovery method, US 2012211366 (A1), 2012.

[24] H. Lyu, K. Chen, X. Yang, R. Younas, X. Zhu, G. Luo, et al., Two-stage nanofiltration process for high-value chemical production from hydrolysates of lignocellulosic biomass through hydrothermal liquefaction, Sep. Purif. Technol. $147 \quad$ (2015) 276-283. doi:10.1016/j.seppur.2015.04.032.

[25] Y. He, D.M. Bagley, K.T. Leung, S.N. Liss, B.Q. Liao, Recent advances in membrane technologies for biorefining and bioenergy production, Biotechnol. Adv. 30 (2012) 817-858. doi:10.1016/j.biotechadv.2012.01.015.

[26] J. Lemaire, C.L. Blanc, F. Duval, M.A. Theoleyre, D. Pareau, Purification of pentoses from hemicellulosic hydrolysates with sulfuric acid recovery by using electrodialysis, Sep. Purif. Technol., 2016. In Press. doi: 10.1016/j.seppur.2016.04.030

[27] G. Liu, Y. Liu, H. Shi, Y. Qian, Application of inorganic membranes in the alkali recovery process, Desalination 169 (2004) 193-205. doi:10.1016/j.biotechadv.2012.01.015. 